\title{
Kontrasepsi Darurat dan Permasalahannya
}

\section{Erna Suparman}

\author{
Bagian Obstetri dan Ginekologi Fakultas Kedokteran Universitas Sam Ratulangi - RSUP \\ Prof. Dr. R. D. Kandou, Manado, Indonesia \\ Email: ernasuparman@yahoo.com
}

\begin{abstract}
Emergency contraception is a contraceptive method that can prevent pregnancy if used immediately following unprotected sex. The use of emergency contraception could reduce the rate of unwanted pregnancy by up to $50 \%$. There are two emergency contraceptive methods, including the emergency contraceptive pill and copper intrauterine device (IUD). Emergency contraceptive pills should be taken immediately following unprotected sex and are most effective when taken within 24 hours. IUD as an emergency contraceptive can be applied five days after unprotected sex, and it does not cause abortion. There is no absolute contraindication for emergency contraception except for known pregnancy, and simply because it is ineffective. The efficacy of emergency contraception can be defined by the proportion of women who become pregnant after using this method and the total pregnancy observed after using the method divided by the estimated number of pregnancies that would occur without using the method.
\end{abstract}

Keywords: emergency contraception; sexual intercourse; pregnancy

\begin{abstract}
Abstrak: Kontrasepsi darurat dapat mencegah kehamilan bila digunakan segera setelah senggama. Penggunaan kontrasepsi darurat dapat menurunkan angka kehamilan yang tidak diinginkan hingga 50\%. Terdapat dua metode kontrasepsi darurat, yaitu pil kontrasepsi darurat dan alat kontrasepsi dalam rahim (AKDR) yang menggunakan tembaga. Pil kontrasepsi darurat harus diberikan sesegera mungkin setelah senggama tidak terlindungi, dan paling efektif bila diberikan dalam waktu 24 jam. AKDR sebagai kontrasepsi darurat dapat dipasang hingga lima hari pasca senggama tidak terlindungi. Kontrasepsi darurat terutama bekerja dengan mencegah fertilisasi, dan tidak menggugurkan kehamilan. Tidak ada kontraindikasi absolut untuk penggunaan kontrasepsi darurat kecuali kehamilan yang diketahui, dan ini hanya karena tidak efektif. Efektivitas kontrasepsi darurat dapat didefinisikan dari proporsi wanita menjadi hamil setelah menggunakan metode ini, dan jumlah kehamilan yang diamati setelah penggunaan dibagi dengan perkiraan jumlah kehamilan yang akan terjadi tanpa penggunaan.
\end{abstract}

Kata kunci: kontrasepsi darurat; senggama; kehamilan

\section{Pendahuluan}

Kontrasepsi darurat adalah kontrasepsi yang dapat mencegah kehamilan bila digunakan segera setelah hubungan seksual. Hal ini sering disebut "kontrasepsi pascasenggama" atau "morning after treatment". Diharapkan dengan kontrasepsi darurat kehamilan yang tidak diinginkan dapat dicegah. Demikian pula tindakan aborsi sebagai upaya penyelesaian kehamilan yang tidak diinginkan dapat dikurangi. Faktor lain tentang penggunaan kontrasepsi darurat ini ialah pada kasus perkosaan. Pemberian kontrasepsi darurat pada seorang wanita juga harus dilihat dari segi bio-psiko-sosial suatu individu, merujuk pada hak-hak reproduksi perempuan untuk dapat menentukan dirinya sendiri dalam memilih kontrasepsi. ${ }^{1}$

Kontrasepsi darurat terkadang dianggap dapat menyebabkan abortus bila digunakan sebagai kontrasepsi darurat. Aborsi medis digunakan untuk mengakhiri kehamilan 
yang sudah ada, sedangkan kontrasepsi darurat hanya efektif sebelum kehamilan terjadi. Kontrasepsi darurat dapat mencegah kehamilan setelah hubungan seksual dan tidak efektif setelah implantasi. Studi terhadap kontrasepsi oral dosis tinggi menunjukkan bahwa kontrasepsi darurat hormonal tidak memberikan risiko pada kehamilan yang sudah terjadi atau membahayakan embrio yang sedang berkembang. ${ }^{1}$

Pada masalah aborsi, terdapat dua gerakan, yaitu pro-life dan pro-choice. Gerakan pro-life berpendapat bahwa kehidupan manusia yang tidak dapat bertahan dan tidak berkembang ialah sakral dan harus dilindungi oleh pemerintah. Aborsi tidak boleh legal dan juga tidak boleh dilakukan secara ilegal. Berbeda halnya dengan gerakan pro-choice yang berpendapat bahwa pada kehamilan sebelum titik viabilitas - ketika janin tidak bisa hidup di luar rahim - pemerintah tidak memiliki hak untuk menghalangi keputusan seorang wanita untuk mengakhiri kehamilan. Gerakan pro-life dan pro-choice saling bertolak belakang namun tujuan mereka sama yaitu mengurangi angka kejadian aborsi, yang membedakan adalah tingkat dan metodologi yang digunakan..$^{2-4}$

Perlindungan terhadap hak reproduksi wanita telah diatur baik oleh hukum internasional maupun nasional. Hukum internasional Convention on the Elimination off All Forms of Discrimination Againts Woman (CEDAW) menyatakan bahwa wanita mempunyai hak untuk perlindungan kesehatan dan keselamatan kerja, termasuk perlindungan fungsi reproduksi. Sementara International Conference on Population and Development (ICPD) di Kairo lebih merinci hak-hak wanita tersebut berupa hak kebebasan berpikir tentang pelayanan kesehatan reproduksi, hak untuk menentukan jumlah dan jarak kelahiran anak, serta hak untuk membangun dan merencanakan keluarga. ${ }^{5}$

Perlindungan terhadap kesehatan reproduksi tertuang dalam Undang-Undang Nomor 36 Tahun 2009 tentang kesehatan dan kedokteran Pasal 72 yang menyatakan setiap orang berhak menjalani kehidupan reproduksi yang sehat dan aman, bebas menentukan sendiri kapan dan berapa sering ingin bereproduksi sehat secara medis, dan memperoleh informasi, edukasi dan konseling mengenai kesehatan reproduksi yang benar. ${ }^{3}$ Undang-Undang Nomor 36 Tahun 2009 pasal 46 menyebutkan: " Untuk mewujudkan derajat kesehatan yang setinggi-tingginya bagi masyarakat, diselenggarakan upaya kesehatan yang terpadu dan menyeluruh dalam bentuk upaya kesehatan perseorangan dan upaya kesehatan masyarakat." Penyelenggaraan upaya kesehatan sebagaimana dimaksud termasuk diantaranya kesehatan reproduksi dan keluarga berencana. ${ }^{5}$ Terkait Undang-Undang Nomor 36 Tahun 2009 pasal 62 ayat (2) berbunyi: "Pencegahan penyakit merupakan segala bentuk upaya yang dilakukan oleh pemerintah, pemerintah daerah dan atau masyarakat untuk menghindari atau mengurangi resiko, masalah dan dampak buruk akibat penyakit."

Mengingat bahwa pemberian informasi yang benar tentang kontrasepsi darurat kepada masyarakat diharapkan dapat membantu masyarakat dan pemerintah dalam memecahkan masalah-masalah kontrasepsi, dengan tetap melihat pada hak reproduksi wanita, terutama untuk menghindari kejadian kehamilan yang tidak diinginkan (unintended pregnancy) dan aborsi maka penulis terdorong untuk membahas mengenai kontrasespi darurat dan permasalahannya.

\section{Kontrasepsi Darurat}

Kontasepsi darurat adalah metode kontrasepsi yang digunakan pasca senggama dan sebelum perkiraan waktu implantasi, yang bertujuan mencegah kehamilan pasca-senggama yang tidak terlindung atau kasus perkosaan. Pengguna kontrasepsi darurat dapat menurunkan angka kehamilan yang tidak diinginkan hingga $50 \%$, tetapi banyak tenaga medis dan masyarakat yang belum mengenal metode ini. ${ }^{1,6}$

Terdapat dua metode kontrasepsi darurat, yaitu pil kontrasepsi darurat dan alat kontrasepsi dalam rahim (AKDR) yang menggunakan tembaga. Telah dikenal dua regimen pil kontrasepsi darurat, yaitu regimen levonorgestrel (LNG) dan regimen 
kombinasi. Regimen LNG memiliki efektivitas yang lebih baik dan menghasilkan lebih sedikit efek samping bila dibandingkan dengan regimen kombinasi. Pil kontrasepsi darurat harus diberikan sesegera mungkin setelah senggama tidak terlindungi, dan paling efektif bila diberikan dalam waktu 24 jam. AKDR sebagai kontrasepsi darurat dapat dipasang hingga 5 hari pasca-senggama tidak terlindungi. Kontrasepsi darurat terutama bekerja dengan mencegah fertilisasi, dan tidak menggugurkan kehamilan. Kontrasepsi darurat sangat aman sehingga dapat ditawarkan kepada wanita yang telah melakukan senggama tidak terlindungi dan ingin mencegah kehamilan. Meskipun demikian, kontrasepsi darurat hanya bersifat sebagai metode cadangan dan tidak digunakan sebagai metode kontrasepsi regular. ${ }^{1,6,7}$

Kontrasepsi darurat (emergency contraception) disebut pula sebagai kontrasepsi pascasenggama karena digunakan setelah melakukan senggama. Hal ini berbeda dengan kontrasepsi pada umumnya yang digunakan sebelum senggama. Kontrasepsi ini sering pula disebut sebagai kontrasepsi sekunder atau morning after pil atau morning after treatment. ${ }^{1,6,7}$ Istilah kontrasepsi sekunder asalnya untuk menepis anggapan bahwa obat tersebut harus segera dipakai atau digunakan setelah senggama atau harus menunggu keesokan harinya. Apabila tidak, berarti sudah terlambat sehingga tidak dapat berbuat apa-apa lagi. Nama untuk keadaan yang darurat, yakni bila terjadi senggama tanpa kontrasepsi atau cara kontrasepsi yang dipakai tidak benar. ${ }^{1}$ Kontrasepsi ini juga untuk menekan bahwa cara KB ini lebih baik dari pada tidak sama sekali, namun tetap kurang efektif bila dibandingkan cara $\mathrm{KB}$ yang rutin dan benar. ${ }^{1,5}$

\section{The Fertile Window}

Hanya selama periode terbatas selama siklus menstruasi, hubungan seksual tanpa kondom dapat menyebabkan kehamilan. Fase subur risiko tinggi meluas dari 5 hari sebelum ovulasi ke hari ovulasi. Fertilisasi harus terjadi dalam 12-24 jam setelah ovulasi, karena setelah waktu itu oosit memburuk dengan cepat dan pembuahan kemudian gagal atau menimbulkan embrio yang rusak. Sebaliknya, spermatozoa dapat bertahan hidup di saluran reproduksi wanita selama 5-6 hati setelah hubungan intim. Dengan demikian, target yang mungkin untuk kontrasepsi darurat ialah: fungsi sperma, maturasi folikel dan ovaluasi, fertilisasi, perkembangan zygote dan transpor melalui tuba Falopii, reseptivitas endometrium dan implantasi embrio, serta fungsi korpus luteum. ${ }^{7}$

Dalam menilai efikasi kontrasepsi darurat, variabilitas ovulasi harus diperhitungkan. Selain itu, perbedaan utama antara laporan diri wanita tentang tahap siklus dan perhitungan penanggalan berdasarkan data endokrin ditunjukkan dalam uji klinis pada efektivitas kontrasepsi darurat. Penelitian juga menunjukkan bahwa frekuensi hubungan seksual dalam siklus menstruasi memuncak selama masa subur sehingga terdapat kemungkinan bahwa dalam populasi wanita yang diberikan kontrasepsi darurat, angka resiko kehamilan yang terjadi cukup bermakna. Karena itu, kontrasepsi darurat harus direkomendasikan kapan saja selama siklus setelah tindakan hubungan seksual tanpa kondom atau kontrasepsi. ${ }^{7}$

\section{Mekanisme Kerja Kontrasepsi Darurat}

Tidak terdapat mekanisme tunggal untuk kontrasepsi darurat. Mode mekanisme bervariasi sesuai dengan hari siklus menstruasi saat hubungan seksual terjadi, waktu dalam siklus menstruasi bahwa kontrasepsi darurat diberikan, dan jenis kontrasepsi darurat yang digunakan. Ulipristal asetat (UPA) dan rejimen khusus levonorgestrel (LNG) telah terbukti menghambat atau menunda ovulasi. LNG menunda perkembangan folikel ketika diberikan sebelum tingkat LH meningkat sedangkan UPA menghambat ruptur folikel bahkan setelah tingkat LH mulai meningkat. Tinjauan bukti menunjukkan bahwa kontrasepsi darurat tidak mungkin mencegah implantasi sel telur yang dibuahi. AKDR tembaga mencegah pembuahan dengan memengaruhi viabilitas dan fungsi sperma; hal ini juga dapat 
memengaruhi oosit dan endometrium. ${ }^{8,9}$

Mekanisme kerja kontrasepsi darurat dapat dibagi atas tiga, yaitu efek terhadap sperma, efek terhadap perkembangan sperma dan ovulasi, dan efek terhadap tuba Falopii. Terkait efek terhadap sperma, data in vitro menunjukkan bahwa LNG dalam dosis yang relevan untuk kontrasepsi darurat tidak memiliki efek langsung pada fungsi sperma. Pengamatan tentang efek LNG pada lendir serviks dan intrauterin mungkin penting ketika LNG digunakan sebagai kontrasepsi biasa tetapi tidak mungkin menjadi mekanisme kerja utama LNG yang digunakan untuk kontrasepsi darurat karena sperma dapat diambil dari tuba Fallopi dalam beberapa menit setelah inseminasi. Selain itu, telah dilaporkan bahwa spermatozoa yang viable ditemukan di saluran genital wanita 24-28 jam setelah mengonsumsi LNG. ${ }^{8,9}$

Dalam hal efek terhadap perkembangan sperma dan ovulasi, LNG telah terbukti memengaruhi perkembangan folikel setelah seleksi folikel dominan tetapi sebelum peningkatan LH dimulai. Ketika pengobatan LNG diberikan pada hari LH-2 atau LH-3, puncak LH dihambat atau ditunda. Efek pada perkembangan folikel bervariasi antara perkembangan folikel yang tertunda, dan folikel yang arrest atau persisten yang tidak pecah. Sebaliknya, pengobatan yang diberikan ketika LH sudah mulai naik, pada hari LH-1 atau pada hari puncak LH, akan gagal menghambat ovulasi. Hasil serupa diperoleh pada hewan model tikus dan kera yaitu bila semakin dekat dengan ovulasi pengobatan diberikan, maka semakin sedikit efeknya. Selain itu, pengobatan dengan LNG pada tikus dan kera tidak memengaruhi pembuahan atau implantasi. ${ }^{8,9}$ Pemberian mifepristone selama fase praovulasi, dilakukan setelah pemilihan folikel dominan, baik menghambat atau menunda ovulasi dengan cara yang tergantung dosis. Pada dosis 1-10 $\mathrm{mg}$, ovulasi tertunda tetapi tidak terhenti. Pada dosis yang lebih tinggi, 200-600 mg, folikel baru sering direkrut. Folikel juga dapat tetap tidak rusak sampai akhir siklus. Ketika ovulasi terjadi, fase luteal berikut tampaknya normal dengan perkembangan dan fungsi endometrium yang normal sebagaimana dinilai oleh tingkat implantasi. Pada tingkat hipofisis, mifepristone tidak menghalangi "naiknya" progesteron, tetapi menghambat kemampuan progesteron untuk bertindak pada progesterone receptor (PR) di hipofisis untuk memfasilitasi lonjakan LH. ${ }^{8-9}$

Mengenai efek terhadap tuba Falopii, lingkungan mikro tuba mungkin sangat penting untuk memastikan perkembangan embrio normal, dan ekspresi reseptor spesifik untuk berbagai faktor pertumbuhan telah ditemukan pada embrio manusia. Transportasi tuba yang terlalu cepat atau terlalu lambat juga dapat menyebabkan desinkronisasi antara embrio dan tuba dan/atau blastokista dan endometrium. Ekspresi PR bergantung secara spasial telah ditunjukkan dalam tuba Fallopi manusia. Tingkat reseptor yang lebih tinggi diekspresikan di daerah ismus daripada daerah ampula tuba pada hari $\mathrm{LH}+4$ hingga +6 . Progesteron telah terbukti mengatur transportasi tuba secara in vitro. Silia dari tuba Fallopi manusia berpulsasi secara bermakna lebih lambat setelah pengobatan dengan progesteron dosis tinggi, efek tersebut dapat dibalikkan dengan mifepristone. Pengobatan dengan LNG (1,5 mg) pada hari $\mathrm{LH}+2$ tidak memengaruhi distribusi reseptor progesteron atau estrogen dalam tuba Fallopi manusia in vitro. Sebaliknya, pemberian $200 \mathrm{mg}$ mifepristone pada hari $\mathrm{LH}+2$ menghasilkan peningkatan ekspresi PR dalam sel epitel dan stroma dibandingkan dengan kontrol yang tidak diobati. Selain itu terdapat juga efek pada tingkat reseptor estrogen meskipun kurang jelas dan masih terbatas pada sel epitel. ${ }^{8,9}$

\section{Indikasi Pemakaian Kontrasepsi Darurat}

Kontrasepsi darurat harus dipertimbangkan untuk setiap wanita yang datang dalam lima hari setelah senggama tanpa kondom atau tidak terlindungi dengan baik dan yang tidak ingin hamil. Pemasangan AKDR tembaga dapat dilakukan hingga tujuh hari setelah hubungan seksual tanpa kondom. Hubungan intim tanpa kondom dapat terjadi karena hal-hal berikut: 
kegagalan menggunakan kontrasepsi; kondom rusak atau bocor saat berhubungan; terlepasnya diafragma atau cervical cap; satu pil KB yang tidak dikonsumsi pada minggu pertama kombinasi pil kontrasepsi kombinasi (SOS [Sesuai Jadwal]); tiga atau lebih pil KB yang tidak dikonsumsi pada minggu kedua atau ketiga pil kontrasepsi kombinasi (algoritma SOS); lupa meminum pil progestin (algoritma SOS); terlepasnya kontrasepsi koyo (algoritma SOS); penghentian kontrasepsi cincin vagina (algoritma SOS); injeksi Depo-Provera terlambat 2 minggu (algoritma SOS); ejakulasi pada genitalia eksterna; dan pemerkosaan. ${ }^{10}$

Karena sulit untuk menentukan dengan pasti waktu dari siklus wanita, kontrasepsi darurat harus diberikan terlepas dari siklus hari di mana paparan terjadi jika seorang wanita khawatir tentang risiko kehamilannya. Meskipun kontrasepsi darurat hormonal tidak direkomendasikan sebagai bentuk kontrasepsi biasa, penggunaan berulang tidak menimbulkan risiko kesehatan yang diketahui dan tidak boleh menjadi alasan untuk menolak akses wanita ke pengobatan. ${ }^{10}$

\section{Kontraindikasi}

Tidak terdapat kontraindikasi absolut untuk penggunaan kontrasepsi darurat kecuali kehamilan yang diketahui, dan hal ini hanya karena tidak efektif. Hasil penelitian telah meyakinkan bahwa obatobat ini tidak bersifat teratogenik. Sebuah studi tentang hasil kehamilan setelah kegagalan kontrasepsi darurat LNG tidak menemukan risiko terkait malformasi atau hasil kehamilan yang merugikan lainnya pada kehamilan yang terpapar dengan kontrasepsi darurat. Studi terhadap kehamilan di mana janin telah terpapar kontrasepsi oral tidak menunjukkan bukti teratogenesitas; oleh karena itu paparan bukan merupakan indikasi untuk penghentian kehamilan. ${ }^{1,10}$

World Health Organization (WHO) tidak mendapatkan kontraindikasi untuk penggunaan kontrasepsi darurat hormonal atau AKDR pada wanita menyusui, dan tidak ada kontraindikasi medis yang diketa- hui untuk penggunaan kontrasepsi darurat hormonal, kecuali alergi terhadap salah satu dari konstituen. ${ }^{11}$ Wanita yang memiliki kontraindikasi terhadap penggunaan kontrasepsi oral setiap hari, seperti perokok di atas usia 35, dapat dengan aman menggunakan salah satu metode kontrasepsi darurat hormonal, karena durasi penggunaan hormon sangat singkat. Tidak ada peningkatan risiko yang substansial untuk terjadinya tromboemboli vena, tetapi studi keselamatan sering mengecualikan wanita yang memiliki kontraindikasi terharap kontrasepsi oral. Rejimen khusus LNG tidak mengandung risiko secara teoritis, oleh karena itu rejimen ini mungkin menjadi pilihan yang lebih baik bagi wanita yang memiliki kontraindikasi kuat terhadap estrogen, seperti wanita yang diketahui memiliki riwayat trombofilia, riwayat stroke, serangan jantung, atau migraine aktif dengan gejala neurologik. Terdapat kekhawatiran bahwa risiko kehamilan ektopik yang berlebihan mungkin dapat terjadi jika kontrasepsi darurat yang hanya mengandung progestin gagal mencegah kehamilan, seperti yang terlihat dengan kontrasepsi progestin saja. Karena pil kontrasepsi darurat efektif dalam menurunkan risiko kehamilan, penggunaannya akan mengurangi kemungkinan tindakan hubungan intim yang akan menyebabkan kehamilan ektopik. ${ }^{1,10}$

Jika AKDR dipertimbangkan sebagai kontrasepsi darurat, terdapat hal-hal yang harus diperhatikan, yaitu: kehamilan harus dieksklusi, hal ini mungkin memerlukan tes kehamilan urin atau tes serum hCG, terutama pada wanita yang telah melakukan hubungan seksual pada awal siklus mereka; tidak ada riwayat penyakit radang panggul dan tidak ada infeksi vagina atau serviks pada pemeriksaan; pada saat pemasangan, dilakukan pengambilan spesimen endoserviks untuk menguji gonore dan klamidia; penggunaan profilaksis antibiotik pada populasi yang berisiko lebih tinggi untuk infeksi menular seksual terbukti mengurangi infeksi panggul berikutnya hingga sepertiga. Antibiotik seperti azitromisin dosis tunggal (1g) atau doksisiklin $200 \mathrm{mg}$ harus dipertimbangkan pada wanita berisiko tinggi 
untuk mengurangi risiko infeksi panggul; jika AKDR gagal mencegah kehamilan, alat harus segera dilepas saat diagnosis kehamilan telah ditegakkan, hal ini penting untuk menyingkirkan kehamilan ektopik.

\section{Jenis Kontrasepsi Darurat}

Kontrasepsi darurat dapat diberikan dalam dua cara pemberian, yaitu mekanik dengan menggunakan AKDR yang mengandung tembaga dan medik (hormonal) yang diberikan secara oral (Tabel 1).

Satu-satunya kontrasepsi darurat mekanik ialah AKDR yang mengandung logam tembaga. Jika dipasang dalam waktu 5-7 hari setelah senggama, AKDR ini mampu mencegah kehamilan. Alat kontrasepsi ini melepaskan ion tembaga yang mematikan sperma dan menyebabkan perubahan pada endometrium sehingga mencegah nidasi. AKDR tembaga pasca senggama menunjukkan bahwa angka kegagalannya tidak lebih dari $0,1 \%$.

Selanjutnya AKDR dapat dipakai terus dan efektif dapat mencegah kehamilan hingga 10 tahun. Cara ini merupakan kontraindikasi bagi wanita yang menderita atau terpapar penyakit menular seksual. ${ }^{1,7,12}$ Penelitian lain membuktikan bahwa penggunaan AKDR tembaga sampai lima hari pasca senggama tanpa perlindungan atau lima hari setelah terjadi ovulasi yang diperkirakan, sangat efektif untuk mencegah kehamilan. Juga AKDR tembaga ini keefektifannya dalam mencegah kehamilan mencapai 99\%.' Memasukkan AKDR dalam lima hari setelah hubungan seksual merupakan metode yang efektif untuk pencegahan kehamilan. Pemasangan AKDR-Cu pasca senggama menghasilkan angka kehamilan mendekati 1 banding 1000 sehingga menjadikannya metode kontrasepsi pasca senggama yang paling efektif. Manfaat dapat diperpanjang hingga 10 hari setelah hubungan intim pada pertengahan siklus yang tidak terproteksi. Mekanisme kerja AKDR-Cu setelah insersi pasca senggama menyerupai aksinya ketika digunakan sebagai kontrasepsi biasa terutama imobilisasi sperma, dan yang kedua, ialah penghancuran oosit dan embrio serta induksi reaksi benda asing. ${ }^{7,12}$
AKDR merupakan pilihan yang baik untuk wanita yang juga menginginkan kontrasepsi jangka panjang. Penelitian lain menunjukkan bahwa wanita pengguna AKDR tembaga pasca senggama sebagai kontrasepsi darurat, mengalami kehamilan pada satu tahun pertama dibandingkan wanita yang menerima kontrasepsi darurat berbasis LNG. ${ }^{7,12}$ Hambatan utama bagi pasien yang memulai AKDR-tembaga setelah berhubungan seks tanpa kondom ialah kurangnya pengetahuan penyedia layanan. Penelitian telah melaporkan bahwa sebagian kecil praktik kebidanan dan kandungan menyadari bahwa AKDR-tembaga dapat digunakan sebagai kontrasepsi darurat, dan bahkan lebih sedikit yang menawarkannya kepada pasien yang mencari kontrasepsi darurat. ${ }^{7,12}$ Terdapat paling sedikit enam cara pemberian kontrasepsi darurat yang telah diteliti secara luas. Metode terbanyak masing-masing bersifat hormonal dan saat ini diterapkan secara oral. Sekalipun pemberian pervaginam sedang dalam tahap penelitian, namun literatur yang telah dipublikasikan masih terbatas pada pemberian oral. ${ }^{1,10}$ Obat-obatan hormonal yang telah disepakati penggunaannya dalam kontrasepsi darurat ialah: progestin, estrogen, kombinasi estrogen-progesteron, antiprogesteron, danazol, dan ulipristal acetate (UPA).

Cara kontrasepsi darurat dengan menggunakan turunan progesteron terdiri dari $0,75 \mathrm{mg}$ LNG yang terbagi dalam dua dosis. Pemberian obat dimulai dalam jangka waktu 48 jam pasca senggama. Walaupun cara ini termasuk yang pertama kali ditemukan tahun 1960, namun hanya sedikit penelitian yang telah dipublikasikan yang menguraikan tentang efektifitas kontrasepsi pasca senggama. Selain itu dilaporkan angka kegagalan sekitar 2,4\%.7,12 Metode kontrasepsi darurat progestin pertama kali diperkenalkan ke pasar AS dengan nama Plan B. Produk Plan B awal terdiri dari dua tablet LNG $0,75 \mathrm{mg}$ yang dikonsumsi dengan interval 12 jam. Percobaan acak telah menunjukkan bahwa konsumsi kedua tablet sebagai dosis tunggal memberikan efektivitas yang sama dibandingkan dengan 
interval 12 jam, tanpa peningkatan efek samping. Plan B One-Step sekarang terdapat di pasaran sebagai pil tunggal yang mengandung LNG $1,5 \mathrm{mg}^{7,12}$ Bila dibandingkan dengan LNG plus estradiol, rejimen khusus LNG memiliki tingkat kegagalan yang sebanding ketika tertelan dalam waktu 48 jam setelah senggama tanpa proteksi, masing-masing sekitar $2 \%$. Beberapa penelitian telah menunjukkan peningkatan efikasi metode LNG dibandingkan metode Yuzpe, yaitu secara substansial lebih sedikit efek mual dan muntah tercatat dengan metode LNG. Mengingat efektivitas yang sebanding dan profil efek samping, metode kontrasepsi darurat yang hanya mengandung progestin sekarang lebih dipilih. ${ }^{7,12}$ Efektivitas paling tinggi dengan metode kontrasepsi darurat apapun ketika diberikan dalam 24 jam setelah hubungan seksual daripada 48 jam berikutnya. Selain itu meskipun studi menguji efektivitas rejimen kontrasepsi darurat dalam waktu 72 jam senggama tanpa kondom, studi yang lebih baru telah menunjukkan efektivitas hingga empat hari, dengan efektivitas yang menurun pada hari kelima penggunaan. Pasien harus diberi tahu bahwa kontrasepsi darurat dapat diminum dalam 120 jam setelah hubungan seksual tanpa proteksi, dengan efektivitas maksimal ketika digunakan sedini mungkin. Sebagian besar penelitian sampai saat ini telah memeriksa efektivitas kontrasepsi darurat setelah satu kali senggama tanpa proteksi, dan didapatkan banyak wanita yang menggunakan kontrasepsi darurat setelah melakukan senggama dua kali atau lebih. ${ }^{7,12}$ Ketika diminum sebelum ovulasi, kontrasepsi darurat berbasis LNG bekerja dengan menghambat lonjakan $\mathrm{LH}$, perkembangan folikel, atau pelepasan ovum, dan dengan demikian mencegah ovulasi. LNG tidak efektif jika diminum saat terjadi ovulasi, karena tidak berpengaruh bermakna terhadap endometrium atau sel telur yang dibuahi. Pada wanita yang hamil walaupun menggunakan kontrasepsi darurat berbasis LNG, tidak terdapat peningkatan risiko keguguran atau dampak pada kesehatan janin. ${ }^{7,12}$ Beberapa penelitian menunjukkan bahwa wanita gemuk mengalami peningkatan risiko kehamilan empat kali lipat setelah menggunakan kontrasepsi darurat LNG bila dibandingkan wanita dengan berat badan normal. Analisis ini menunjukkan ketidakefektifan metode ini pada wanita dengan berat lebih dari $80 \mathrm{~kg}$. Wanita yang kelebihan berat badan dan obes yang mencari kontrasepsi darurat harus ditawarkan AKDR sebagai pilihan yang paling efektif, tetapi Centers for Disease Control and Prevention (CDC), American College of Obstetricians and Gynecologists (ACOG), dan Food and Drug Administration (FDA) menyetujui bahwa penelitian lebih lanjut diperlukan., ${ }^{7,2}$

Pemberian estrogen dosis tinggi sama efektifnya seperti metode Yuzpe namun efek sampingnya lebih sering timbul. Pada setiap kasus, pemberian estrogen dosis tinggi harus diberikan dalam waktu 72 jam setelah senggama. Hal ini penting diketahui karena bila sampai lebih dari 72 jam disamping kurang berguna akan menimbulkan efek teratatogen. Pil diminum 2 x sehari selama 5 hari, satu kali minum setara dengan $25 \mathrm{mg}$ DES. Etinil estradiol dibutuhkan 2,5 $\mathrm{mg}$ per dosis sedangkan estrogen yang teresterifikasi dan terkonyugasi masingmasing dibutuhkan 2,5 mg per dosis. ${ }^{7,12}$

Untuk kombinasi estrogen-progesteron, secara keseluruhan cara ini terdiri dari 200 $\mu \mathrm{g}$ etinilestradiol dan $1,0 \mathrm{mg}$ LNG. Pemberian dapat dimulai segera setelah senggama hingga 72 jam kemudian dengan dosis 100 $\mu \mathrm{g}$ etinilestradiol dan $0,5 \mathrm{mg}$ LNG dengan dosis yang sama diulang 12 jam kemudian. ${ }^{7,12}$ Cara ini cukup popular karena hormon yang digunakan setara dengan beban aktif yang ditemukan dalam pil KB, yang mudah didapat dan telah beredar di pasaran. Metode ini juga dikenal sebagai metode Yuzpe. 7,12 Efek samping metode Yuzpe sama seperti yang ditemukan pada pemakaian pil KB, yaitu nausea (termasuk muntah pada $20 \%$ kasus), sakit kepala, nyeri payudara, nyeri abdomen dan pusing. Efek samping yang sering dilaporkan ialah nausea, yakni 50\% dari wanita yang mengalami efek samping. Nausea dapat dicegah dengan minum pil bersamaan dengan makanan atau susu. Beberapa dokter secara rutin memberikan 
metode Yuzpe ini dengan pemberian antiemetik sebelumya. ${ }^{7,12}$

Metode baru dengan pemakaian anti progestin ini dapat digunakan tanpa mengindahkan tenggang waktu setelah senggama yang tidak terlindungi. Tidak penting pula kapan atau berapa kali hubungan seksual dilakukan asal diberikan pada fase luteal. Jika anti progestin diberikan pada fase luteal, pendarahan ini terjadi tanpa memandang adanya hasil pembuahan dini atau hasil konsepsi tersebut telah nidasi atau belum. ${ }^{7,12}$ Pada dua penelitian yang telah mengevaluasi penggunaan mifepristone sebagai kontrasepsi darurat dengan studi prespektif tidak didapatkan satu kehamilan pun dalam kedua penelitian tersebut. Pemberian mifepristone dengan dosis tunggal $600 \mathrm{mg}$ dengan tenggang waktu 72 jam pasca senggama. Dosis yang lebih rendah mungkin saja efektif dan waktu pemberian bisa saja melewati 72 jam. ${ }^{7,12}$

Danazol/Danacrine dapat digunakan untuk kontrasepsi darurat, dengan dosis $2 \mathrm{x}$ $400 \mathrm{mg}$ yang diberikan selang 12 jam, seperti halnya dengan metode Yuzpe. Varian lain juga telah diteliti ialah pemberian dosis 3 x $400 \mathrm{mg}$ dengan selang 12 jam. Keuntungan danazol antara lain karena jarang terjadi efek samping. Efek samping yang mungkin terjadi tidak terlalu berat dibandingkan dengan metode Yuzpe. Danazol dapat diberikan pada wanita yang mempunyai kontraindikasi terhadap pil KB atau estrogen namun kerugiannya ialah kurangnya informasi tentang cara ini dan harganya yang relatif mahal. ${ }^{7,12}$

Ulipristal acetate (UPA) ialah modulator reseptor progesteron yang merupakan turunan dari 19-norprogesteron dan dikembangkan untuk meningkatkan spesifisitas terhadap PR. UPA diberikan sebagai dosis tunggal $30 \mathrm{mg}$ dan dapat dikonsumsi dalam 120 jam setelah hubungan intim tanpa kondom $^{7,12}$ Antiprogestin mungkin lebih efektif daripada progestin karena kemampuannya untuk menunda ovulasi dan menghambat implantasi. UPA dapat menunda ovulasi sampai lima hari dan tampaknya efektif pada fase folikel lanjut, bahkan setelah kadar LH mulai meningkat, yaitu periode ketika LNG tidak lagi efektif dalam menghambat ovulasi. Penelitian telah menemukan bahwa UPA setidaknya atau lebih efektif daripada LNG pada semua interval waktu (0 smapai 24 jam, 0 hingga 72 jam, 0 hingga 120 jam).

Tabel 1. Ringkasan jenis kontrasepsi darurat

\begin{tabular}{|c|c|c|c|c|}
\hline Cara & Jenis & Merek Dagang & Dosis & Waktu Pemberian \\
\hline Mekanik & AKDR-Cu & $\begin{array}{l}\text { Cooper T Multiload } \\
\text { Nova Y }\end{array}$ & $\begin{array}{l}\text { Satu kali pe- } \\
\text { masangan }\end{array}$ & $\begin{array}{l}\text { Dalam waktu tujuh hari } \\
\text { pasca senggama }\end{array}$ \\
\hline \multirow[t]{6}{*}{ Medik } & $\begin{array}{l}\text { Pil kombina- } \\
\text { si dosis ting- } \\
\text { gi }\end{array}$ & $\begin{array}{l}\text { Microgynon } 50 \text { Ovral } \\
\text { Neogynon Nordiol } \\
\text { Eugynon }\end{array}$ & $2 \times 2$ tablet & $\begin{array}{l}\text { Dalam waktu lima hari pasca } \\
\text { senggama, dosis kedua } 12 \\
\text { jam kemudian }\end{array}$ \\
\hline & $\begin{array}{l}\text { Pil kombina- } \\
\text { si dosis ren- } \\
\text { dah }\end{array}$ & $\begin{array}{l}\text { Microgynon } 30 \\
\text { Mikrodiol Nordette }\end{array}$ & $2 \times 4$ tablet & $\begin{array}{l}\text { Dalam waktu lima hari pasca } \\
\text { senggama, dosis kedua } 12 \\
\text { jam kemudian }\end{array}$ \\
\hline & Progestin & Postinor-2 Valenor & $2 \times 1$ tablet & $\begin{array}{l}\text { Dalam waktu lima hari pasca } \\
\text { senggama, dosis kedua } 12 \\
\text { jam kemudian }\end{array}$ \\
\hline & Estrogen & $\begin{array}{l}\text { Lynoral Premarin } \\
\text { Progynova }\end{array}$ & $\begin{array}{l}2,5 \mathrm{mg} / \mathrm{dosis} \\
0,625 \mathrm{mg} / \mathrm{dosis} \\
10 \mathrm{mg} / \mathrm{dosis}\end{array}$ & $\begin{array}{l}\text { Dalam waktu lima hari pasca } \\
\text { senggama, } 2 x 1 \text { dosis selama } \\
\text { lima hari }\end{array}$ \\
\hline & Mifepriston & RU-486 & $1 \times 100 \mathrm{mg}$ & $\begin{array}{l}\text { Dalam waktu lima hari pasca } \\
\text { senggama }\end{array}$ \\
\hline & Danazol & Danocrin Azol & $2 \times 4$ tablet & $\begin{array}{l}\text { Dalam waktu lima hari pasca } \\
\text { senggama, dosis kedua } 12 \\
\text { jam kemudian }\end{array}$ \\
\hline
\end{tabular}


Tidak terdapat perbedaan dalam profil efek samping dari kedua obat, dan keduanya aman digunakan pada hampir semua wanita. Penelitian menunjukkan efektivitas UPA memiliki resiko kegagalan mencegah kehamilan dua kali lebih besar pada wanita gemuk dibandingkan wanita dengan BB normal, tetapi penggunaan UPA masih lebih disukai dibandingkan penggunaan LNG pada populasi penelitian ini. ${ }^{7,12}$

\section{Efek Samping}

Tidak dilaporkan terjadinya kematian atau komplikasi serius yang dikaitkan dengan kontrasepsi darurat. Efek samping jangka pendek meliputi mual dan sakit kepala, pendarahan tidak teratur, efek saming lainnya, dan risiko perforasi uterus. Produk UPA dan LNG memiliki profil efek samping serupa, dan yang paling sering dilaporkan ialah sakit kepala (19\%) dan mual (21\%). Regimen estrogen-estrogen gabungan memiliki tingkat mual yang secara bermakna lebih tinggi daripada rejimen UPA dan LNG. ${ }^{10}$

Setelah penggunaan pil kontrasepsi darurat, periode menstruasi biasanya terjadi dalam satu minggu dari waktu yang diharapkan. Beberapa pasien mengalami pendarahan tidak teratur atau bercak pada minggu atau bulan setelah penggunaan. Suatu penelitian terhadap rejimen LNG mendapatkan bahwa $16 \%$ wanita melaporkan pendarahan nonmenstruasi pada minggu pertama setelah penggunaan. Jika kontrasepsi darurat diminum lebih awal dalam siklus, kemungkinan besar seorang wanita akan mengalami pendarahan sebelum menstruasi yang diharapkan. Pendarahan yang tidak teratur terkait dengan kontrasepsi darurat sembuh tanpa pengobatan. ${ }^{1,10}$

Efek samping lainnya ialah beberapa pasien telah melaporkan mengalami efek samping jangka pendek lainnya dengan rejimen oral, seperti: nyeri payudara, nyeri perut, pusing, dan kelelahan. ${ }^{1,10}$

Pemasangan AKDR memiliki risiko perforasi uterus sekitar 1/1.000, dan dapat menyebabkan peningkatan durasi menstruasi atau dismenore. ${ }^{1,10}$

\section{Efektivitas Kontrasepsi Darurat}

Untuk kontrasepsi darurat, efektivitas dapat didefinisikan dalam satu dari dua cara: 1) proporsi wanita menjadi hamil setelah menggunakan metode ini; 2) jumlah kehamilan yang diamati setelah penggunaan dibagi dengan perkiraan jumlah kehamilan yang akan terjadi tanpa penggunaan. Ketika proporsi ini dikurangi beberapa dari keseluruhan, statistik yang dihasilkan ialah "prevented fraction" yang mewakili perkiraan persentase kasus yang menghindari terapi. Angka-angka yang dilaporkan tentang kemanjuran kontrasepsi darurat sangat bervariasi dan tidak tepat. ${ }^{1,7,10,12}$

Penggunaan AKDR dievaluasi dalam uji coba multisenter di kalangan wanita yang meminta kontrasepsi darurat hingga lima hari setelah melakukan senggama tanpa proteksi. Di antara 1.893 wanita, tidak ditemukan kehamilan dalam bulan pertama. Tinjauan kajian sistematik yang dipublikasikan mengenai penggunaan AKDR sebagai kontrasepsi darurat mengidentifikasi 42 studi dalam jangka waktu 35 tahun. Tingkat kehamilan yang dilaporkan ialah antara $0 \%$ dan $2 \%$ pada studi terbesar. ${ }^{1,7}$ Studi terbesar kedua, yang melibatkan 1.013 wanita, menunjukkan terjadinya satu kehamilan dengan tingkat $0,1 \% .^{10,12}$

Regimen oral juga telah dievaluasi secara holistik. Penelitian telah mendapatkan bahwa UPA lebih efektif daripada rejimen khusus LNG dan mempertahankan keefektivitasnya hingga lima hari. Sebuah meta-analisis dari uji efikasi komparatif menemukan tingkat kehamilan yang lebih rendah di antara pengguna UPA $(1,4 \%)$ dibandingkan dengan pengguna rejimen LNG saja $(2,2 \%)$. Studi fase III memiliki tingkat kehamilan keseluruhan 1,9\% untuk wanita yang menggunakan UPA. Enam studi yang terdiri dengan total lebih dari 8.000 perempuan yang menggunakan rejimen LNG menghitung tingkat pencegahan mulai dari $60 \%$ hingga $94 \%$. Demikian pula, delapan studi termasuk total lebih dari 3.800 wanita yang menggunakan rejimen estrogen-progestin kombinasi menghasilkan tingkat pencegahan mulai dari 56\% hingga $89 \%$. Meta-analisis data yang dikumpulkan 
dari studi ini menyimpulkan bahwa rejimen estrogen-progestin gabungan mencegah setidaknya $74 \%$ dari kehamilan yang diharapkan. ${ }^{1,7,10,12}$

Terdapat dua studi mengenai efektivitas rejimen LNG dibandingkan dengan rejimen kombinasi estrogen-progestin. Studi pertama tidak mendapatkan perbedaan bermakna secara statistik dalam tingkat kehamilan antara rejimen LNG dan rejimen kombinasi (masing-masing 2,4\% berbanding 2,7\%). Namun, studi kedua yang lebih besar melaporkan bahwa rejimen LNG secara bermakna lebih efektif untuk mencegah kehamilan daripada rejimen kombinasi (masingmasing $85 \%$ berbanding $57 \%$ kehamilan yang dapat dicegah). ${ }^{1,7}$ Perkiraan berdasarkan data gabungan dari dua studi ini menunjukkan penurunan risiko relatif kehamilan (risiko relatif 0,51 ; interval kepercayaan 95\%, 0,31-0,83) dengan rejimen khusus LNG saja. Rejimen khusus LNG untuk kontrasepsi darurat lebih efektif daripada rejimen hormonal kombinasi dan dikaitkan dengan mual dan muntah yang lebih sedikit. Oleh karena itu, rejimen khusus LNG lebih disukai daripada rejimen kombinasi estrogen-progestin. ${ }^{10,12}$

Berat badan memengaruhi efektivitas kontrasepsi darurat oral. Kontrasepsi darurat LNG mungkin kurang efektif pada wanita yang kelebihan berat badan (indeks massa tubuh/IMT 25-29,9 kg/m2) atau obesitas (IMT $30 \mathrm{~kg} / \mathrm{m} 2$ atau lebih besar). Selain itu, beberapa penelitian menunjukkan bahwa UPA memiliki efektivitas yang lebih rendah pada wanita obes. Efektivitas AKDR tidak dipengaruhi oleh berat badan. Oleh karena itu, pertimbangan harus diberikan untuk penggunaan AKDR sebagai alternatif kontrasepsi darurat pada wanita obes. Namun, kontrasepsi darurat oral tidak boleh dijadikan kontraindikasi absolut dari wanita yang kelebihan berat badan atau obes karena hingga saat ini belum terdapat penelitian yang didukung secara memadai untuk mengevaluasi ambang batas berat badan di mana kontrasepsi darurat oral menjadi tidak efektif. ${ }^{1,7,10,12}$

Untuk memaksimalkan efektivitas, wanita harus dididik tentang ketersediaan kontrasepsi darurat sebelum dibutuhkan. Beberapa uji coba terkontrol secara acak gagal menunjukkan penurunan kehamilan atas aborsi yang tidak diinginkan dengan peningkatan akses ke kontrasepsi darurat. Data ini menyoroti pentingnya konseling pasien tentang penggunaan kontrasepsi darurat yang tepat sebagai intervensi episodik daripada metode jangka panjang yang efektif. Informasi mengenai metode kontrsepsi jangka penjang yang efektif harus tersedia setiap kali seorang wanita meminta kontrasepsi darurat, dan pertimbangan harus diberikan untuk pengguna AKDR, yang sangat efektif sabagai kontrasepsi darurat dan kontrasepsi yang sedang berlangsung. Penggunaan metode reversibel jangka panjang yang sangat efektif harus didorong penggunaannya melalui konseling dan edukasi. ${ }^{1,7,10,12}$

\section{Simpulan}

Kontrasepsi darurat merupakan salah satu cara kontrasepsi yang cukup efektif dalam mencegah kehamilan. Berbagai jenis dan mekanisme kerja kontrasepsi darurat saat ini telah diketahui, namun efektivitasnya bervariasi karena dipengaruhi oleh banyak faktor, seperti saat senggama terjadi, waktu dalam siklus menstruasi, saat kontrasepsi darurat diberikan, dan jenis kontrasepsi daruat yang digunakan. Pada prinsipnya, kontrasepsi darurat bekerja dengan mencegah ovulasi atau mencegah viabilitas sperma sehingga kemampuan sperma berkurang untuk membuahi. Jutaan kehamilan yang tidak dikehendaki dan atau aborsi dapat dicegah apabila kontrasepsi darurat dapat diterima dan tersedia secara luas, dan juga dipahami oleh pemberi pelayanan kesehatan.

\section{Konflik Kepentingan}

Penulis menyatakan tidak terdapat konflik kepentingan dalam studi ini.

\section{DAFTAR PUSTAKA}

1. Raymond E, Pradhan A, Keder L. Practice bulletin No.152: Emergency contraception. Obstet Gyncool. 2015;126(3): e1-11. 
2. The Lancet. Sexual health and reproductive rights at a crossroad: Editorial [Internet]. Lancet. 2017;390(10089):1. Available from: http://dx.doi.org/10.1016/S01406736(17)31750-6

3. WHO. Ensuring human rights in the provision of contraceptive information and services. WHO Libr Cat Data: 2014;12-24.

4. O'Hara E. Pro-life or pro-choice? Pro-rights [Internet]. Institute of Development Studies. 2018 [cited 2018 Mar 1]. Available from: http://www.ids.ac.uk/ opinions/pro-life-or-pro-chioce-prorights/

5. Widanti A. KB dihubungkan dengan program jaminan persalinan (PERMENKES NO. 2562/MENKES/PER/XXI/2011).

SOEPRA J Huk Kesehat. 2017;3 (2562):185-93.

6. The Association of Women's Health, Obstetric and Neonatal Nurses (AWHONN). Emergency contraception. J Obstet Gynecol Neonatal Nurs [Internet]. 2017; 46(6):886-8. Available from: https://doi. org/10.1016/j.jogn.2017.09.004

7. Fritz MA, Speroff L. Contraception. In: Fritz MA, Speroff L, editors. Clinical Gynecologic Endocrinology and Infertility (8th ed). Philadelphia: Lippincott
Williams \& Wilkins, A Wolters Kluwer business, 2011; p. 1040-4.

8. Gemzell-Danielsson K, Berge C, Lalitkumar PGL. Emergency contraception mechanisms of action. Contraception [Internet]. 2013;87(3):300-8. Available from: http://dx.doi.org/10.1016/j.contra ception.2012.08.021

9. Trussell J, Jordan B. Mechanism of action of emergency contraceptive pills. Contraception 2006;74;87-9.

10. Clark V, Bc G, Davis V, On S, Rutherford M, $\mathrm{Ns} \mathrm{H}$, et al. Emergency Contraception. J Obstet Gynecol Canada [Internet]. 2012;34(9):870-8. Available from: http://dx.doi.org/10.1016/S1701-2163 (16) $35387-7$

11. Altshuler AL, Gaffield ME, Kiarie JN. The WHO's medical eligibility criteria for comtraceptive use: 20 years of global guidance. Curr Opin Obstet Gynecol [Internet]. 2015;27(6):451-9. Available from: https://www.ncbi.nlm.nih.gov/ pubmed/26390246

12. Schreiber CA, Barnhart K. Contraception. In: III JFS, Barbieri RL, Gargiulo AR, editors. Yen \& Jaffe's Reproductive Endocrinology (8th ed). Philadelphia: Elsevier Ltd, 2019; p. 970-4. 